Int. J. Morphol.,

33(3):850-854, 2015

\title{
Body Composition Comparisons by Age Groups in Hungarian Adults
}

\author{
Comparaciones de Composición Corporal en Grupos Etarios de Adultos Húngaros
}

\author{
Ferenc Ihász"; Kevin. J. Finn"*; Josip Lepes ${ }^{* * *}$; Sabolc Halasi**** \& Péter Szabó*
}

IHÁSZ, F.; FINN, K. J.; LEPES, J.; HALASI, S. \& SZABÓ, P. Body composition comparisons by age groups in Hungarian adults. Int. J. Morphol., 33(3):850-854, 2015.

SUMMARY: The assessment of body composition provides a basis for evaluating changes in adults as they age. If the fat content is shown to be too high, intervention to reduce storage fat is warranted. The purpose of this paper is to report differences in body composition in men and women across three age groups (young, middle aged, older) to describe potential changes in both fat and muscularity. In addition, if fat storage is shown to be located in the visceral area (around the internal organs), then an addition risk to health would be evident. A total of 1564 Hungarian adults were tested for body mass index (BMI) and body composition using a multifrequency electrical impedance device to determine percent body fat (PBF), percent muscularity (M\%), and visceral fat area. Descriptive analyses were performed and Analyses of Variance were used to compare the mean values from each of the three groups. Post hoc comparisons were performed on significant findings. The results of this study indicate an increase in BMI, PBF, and visceral fat area and a decrease in $\mathrm{M} \%$. These differences were evident in young compared to middle-aged and older adults and between middle-aged and older adults. Levels of muscularity were significantly less as age increased. This resulted in no significant differences in BMI between middle-aged and older adults. This reduction in muscularity is alarming in that prior to expected age for sarcopenia, the middle-aged adults were showing declines in tissue that would benefit their quality of life. Longitudinal studies are needed to confirm these findings.

KEY WORDS: Body composition; Age groups; Males; Females.

\section{INTRODUCTION}

The changes in body mass in adults are subjective to retention of skeletal muscle, accumulation of fat storage, and alterations in the composition of bone and organ density. While we expect little change in stature, the body mass can fluctuate between $10-50 \%$ over the course of a lifetime. In these changes alterations of body composition is possible and in the case of aging, expected. Changes in body composition can very often cause chronic diseases, and as a result have become a primary concern (Bae et al., 2013). For instance, sarcopenia, or lose of skeletal muscle is part of the aging process regardless of physical activity in older adults (Rosenberg \& Roubenoff, 1995). Age-related physiological changes affect a broad range of tissues, organ systems and functions, and can cumulatively impact successes and activities of daily living (American College of Sports Medicine et al., 2009). A strong link has been established between decreased muscle strength, physical capacity, quality of life, and the loss of fat-free mass (Katula et al.,
2006) Many times lost tissue is replaced by other tissue of lower density (i.e. fat cells). Skeletal muscle loss or sarcopenia characterizes a feature of ageing and also occurs in healthy independently living older adults who may not present weight loss (Gallagher et al., 2000a).

In medical examinations, a measure of body mass index (BMI) is calculated. If the BMI exceeds $25 \mathrm{~kg} / \mathrm{m} 2$, then the patient is considered overweight and if over $30 \mathrm{~kg} /$ $\mathrm{m} 2$, they are classified as obese. There has been a debate in using BMI alone as the indicator of obesity. Romero-Corral et al. (2008) suggested caution in using BMI only since it underestimated the total numbers of obesity adults (based upon body fat percentage) in NHANES III.

The purpose of this study was to investigate BMI in adults and contrast the levels of adiposity across sex and age categories. For this study, a fairly new instrument that

\footnotetext{
* University of West Hungary, Apáczai Csere János Faculty, Gyo"r, Hungary.

** University of Northern Iowa, School of Health, Physical Education, and Leisure Services, Cedar Falls, USA.

${ }^{* * *}$ University of Novi Sad, Teachers' Training Faculty in Hungarian, Subotica, Serbia.
} 
uses multi-frequency bioelectrical impedance was utilized which has been shown to be valid in the assessment of total body water and segmental lean body mass (Bedogni et al., 2002) and its administration is feasible in a clinical setting. In addition, for the European marketed device, the interpretation includes an estimate of visceral fat as part of the evaluation. This fat area (usually around the abdominal area) has been linked to heart disease, an additional fat deposit commonly found in aging adults.

\section{MATERIAL AND METHOD}

Subjects. For this study, a convenient sample of adults was measured in the northwestern region of Hungary over a four year period (2011-2014). The Ethics/Bioethics Committee at the University of West Hungary approved the protocols of this research. Subjects were separated by sex and group according to ages ranging from 20-40 years (young), 41-60 years (middle aged), and 61-80 years (old). These age ranges were chosen to reflect the body composition groupings in recommendations supported by the World Health Organization (Gallagher et al., 2000b).
The total participation by sex was 1198 females and 466 males. The numbers of females in each age category were 307 young, 486 middle-aged, and 405 older adults (Table I). For males, the age category totals were 135, 182, and 149 for young, middle-aged, and older adults respectively (Table II).

Instrumentation. The InBody 720 (Biospace Co. Inc., Seoul, South Korea) Bioelectrical Impedance Analyzer (BIA) was used. This foot-to-foot, hand-to-hand and handto-foot contact device uses two stainless-steel foot pad electrodes mounted on a platform scale and two stainlesssteel handles to allow for Tetrapolar 8-point tactile electrode system. The reliability of bioelectrical-impedance analysis compared to other body composition measurement methods, like DXA, has been successfully demonstrated (Shafer et al., 2009; Gibson et al., 2008; Sun et al., 2005). The platform scale uses a single load cell to measure body mass (which with a measure of stature) and calculate body mass index (BMI). Body fat percentage (PBF) is determined using a summation of segmental lean analysis to determine total lean body mass, fat mass, and ultimately the proportion of fat to total weight mass fraction. An estimate of muscular percentage $(\mathrm{M} \%)$ is derived by

Table I. Descriptive data and ANOVA (with Tukey post hoc) for females.

\begin{tabular}{|c|c|c|c|c|}
\hline $\begin{array}{l}\text { Age groups } \\
\text { (female) } \\
\text { Variable } \\
\end{array}$ & $\begin{array}{c}\text { Young }(\text { G1) } \\
(\mathrm{n}=\mathbf{3 0 7})\end{array}$ & $\begin{array}{c}\begin{array}{c}\text { Middle aged (G2) } \\
(n=486)\end{array} \\
\text { Mean } \pm \text { SD } \\
\end{array}$ & $\begin{array}{c}\text { Old (G3) } \\
(n=405)\end{array}$ & $\mathbf{F}$ \\
\hline BMI & $23.41 \pm 4.34 * \dagger$ & $27.74 \pm 5.54 \ddagger$ & $29.36 \pm 4.85$ & $147.59 * * *$ \\
\hline PBF & $27.75 \pm 8.22 * \dagger$ & $35.53 \pm 7.93 \ddagger$ & $39.67 \pm 6.99$ & $911.37 * * *$ \\
\hline М\% & $39.60 \pm 4.62 * \dagger$ & $35.21 \pm 4.38 \ddagger$ & $32.56 \pm 3.88$ & $232.92 * * *$ \\
\hline VFA & $61.40 \pm 30.92 * \dagger$ & $120.84 \pm 30.96 \neq$ & $150.08 \pm 26.74$ & $259.69 * * *$ \\
\hline
\end{tabular}

Abbreviations: $\mathrm{BMI}=$ body mass index $\mathrm{PBF}=$ percentage body fat; $\mathrm{M} \%=$ percentage skeletal muscle; $\mathrm{VFA}=$ visceral fat area; $\mathrm{SD}=$ Standard deviation; $\mathrm{F}=$ Analysis of variance (ANOVA).

$* * *$ Significant differences between age groups; $\mathrm{p}<0.001$. * Significant differences between group G1 and G3; $\mathrm{p}<0.001 . \dagger$ Significant differences between group G1 and G2; $<0.001 . \ddagger$ Significant differences between group G2 and $\mathrm{G} 3 ; \mathrm{p}<0.001$.

Table II. Descriptive data and ANOVA (with Tukey post hoc) for males.

\begin{tabular}{lcccr}
\hline $\begin{array}{l}\text { Age groups } \\
(\text { male })\end{array}$ & $\begin{array}{c}\text { Young }(\mathbf{G 1}) \\
(\mathbf{n}=\mathbf{1 3 5})\end{array}$ & $\begin{array}{c}\text { Middle aged }(\mathbf{G 2}) \\
(\mathbf{n = 1 8 2})\end{array}$ & $\begin{array}{c}\text { Old }(\mathbf{G 3}) \\
(\mathbf{n = 1 4 9})\end{array}$ & \multirow{2}{*}{$\mathbf{F}$} \\
\cline { 1 - 4 } Variable & Mean \pm SD & Mean \pm SD & Mean \pm SD & \\
\hline BMI & $25.61 \pm 3.85^{* \dagger}$ & $28.29 \pm 4.31$ & $28.82 \pm 3.73$ & $34.10^{* * *}$ \\
PBF & $18.27 \pm 7.45^{* \dagger}$ & $26.05 \pm 7.46 \ddagger$ & $29.63 \pm 6.83$ & $156.65^{* * *}$ \\
M\% & $46.51 \pm 4.33^{* \dagger}$ & $41.57 \pm 4.35 \ddagger$ & $38.99 \pm 3.93$ & $109.54^{* * *}$ \\
VFA & $78.43 \pm 49.77^{* \dagger}$ & $140.93 \pm 30.92 \ddagger$ & $164.60 \pm 44.94$ & $138.42^{* * *}$ \\
\hline
\end{tabular}

Abbreviations: $\mathrm{BMI}=$ body mass index $\mathrm{PBF}=$ percentage body fat; $\mathrm{M} \%=$ percentage skeletal muscle; $\mathrm{VFA}=\mathrm{visceral}$ fat area; $\mathrm{SD}=$ Standard deviation; $\mathrm{F}=$ Analysis of variance (ANOVA).

*** Significant differences between age groups; $\mathrm{p}<0.001$. * Significant differences between group G1 and G3; $\mathrm{p}<0.001$. $\dagger$ Significant differences between group G1 and G2; $<<0.001$. Significant differences between group G2 and $\mathrm{G} 3 ; \mathrm{p}<0.001$. 
evaluating water content in the segmental regions using proprietor equations. The estimate of visceral fat area (VFA) is displayed from regression equations (proprietor) stated by the manufacturer to be derived from comparison of visceral fat to computerized tomography scans to impedance in the torso region using segmental lean analysis of the torso. Body stature was measured using stadiometer.

Procedures. The subjects entered the testing area and removed their shoes and socks and wore only light clothing. The stature of the subject was taken with a hand held stadiometer standing erect. Positioned on the In-Body 720, the age, sex, and stature were entered. The InBody 720 displays a visual cue (photo) how and when to hold the handles during the impedance measure.

Statistical Analyses. The subject number, sex, age, BMI, PBF, M\% and VFA were transferred to an Excel file and then imported into the STAT program (version 11.0). A frequency distribution determined the number of subject by sex and age categories while descriptive analysis was conducted on BMI, PBF, M\%, and VFA. An Analysis of Variance (ANOVA) for each variable by age group (separating gender) was performed testing significance at the $95 \%$ level of confidence with Tukey post hoc comparisons.

\section{RESULTS}

Using the body mass index (BMI) standards from the World Health Organization (2012), the percentage of normal weight (less than $25 \mathrm{~kg} / \mathrm{m}^{2}$ ) persons were $38 \%$, the percentage of overweight $\left(25-29.9 \mathrm{~kg} / \mathrm{m}^{2}\right)$ adults were $36 \%$ and the percentage of obese $\left(30.0 \mathrm{~kg} / \mathrm{m}^{2}\right.$ and above) were $26 \%$ including all age groups and both sexes.

The results of the ANOVA indicate a significant change in mean BMI across the age groups (Tables I and II) The BMI

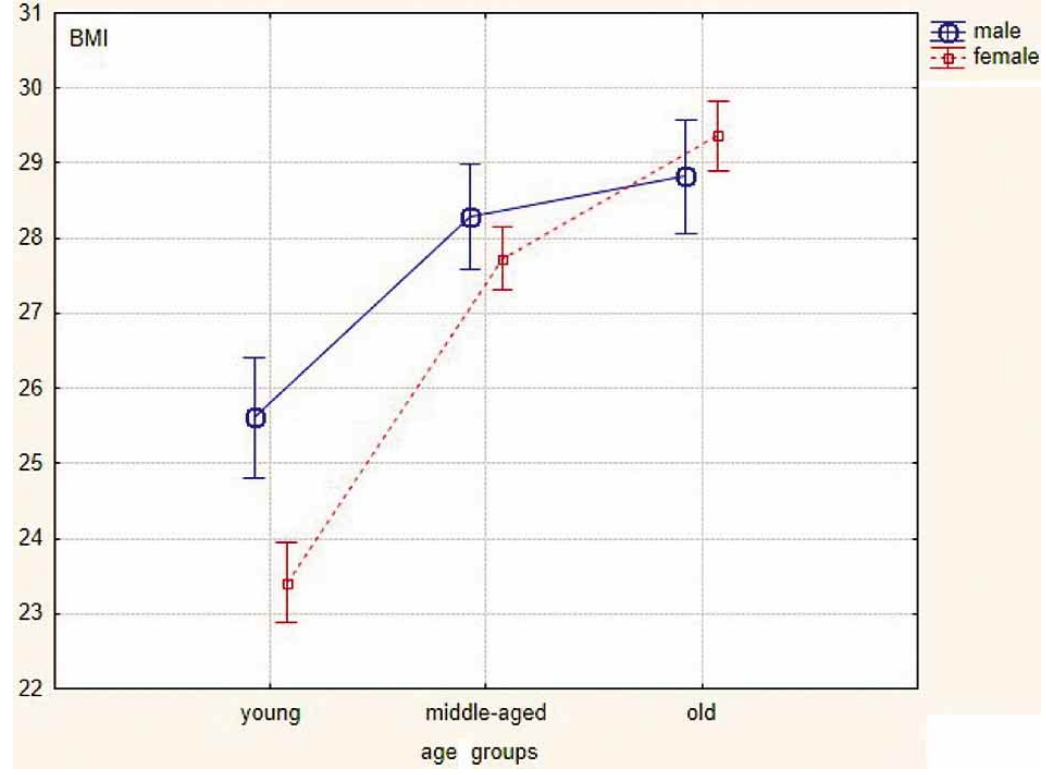

Fig. 1. Mean Body Mass Index (BMI) for males and females by age group.

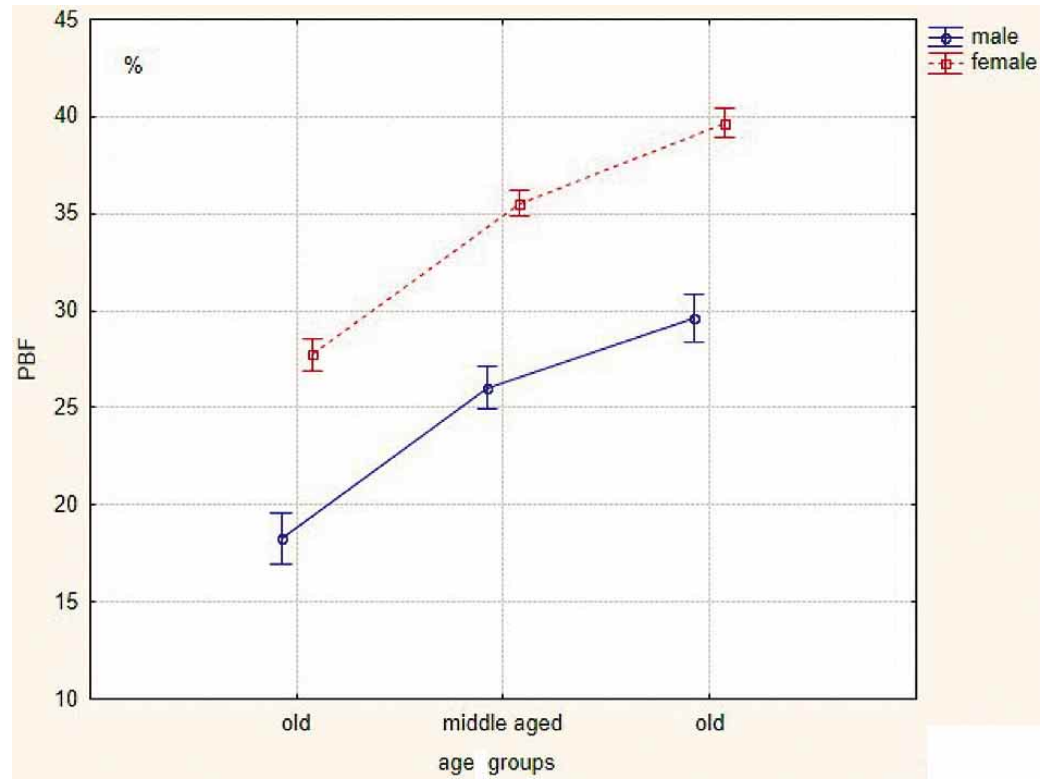

Fig. 2. Mean Percent Body Fat (PBF) for males and females by age group.

increased significantly in both sexes $(\mathrm{p}<0.001)$ from young to middleaged. The BMI increased significantly (Fig. 1) from middle-aged to older adults in the females $(\mathrm{p}<0.001)$, however not between the middle-aged and older males $(\mathrm{p}=0.448)$. The PBF increased significantly (Fig. 2) between young and middle-aged $(\mathrm{p}<0.001)$ and continued to increase in older adults for both sexes $(\mathrm{p}<0.001)$. The percentage of muscularity decreased (Fig. 3) across the age groups all three age groups $(\mathrm{p}<0.001)$ in both sexes. The visceral fat area significantly increased (Fig. 4) in both sexes $(\mathrm{p}<0.001)$. 


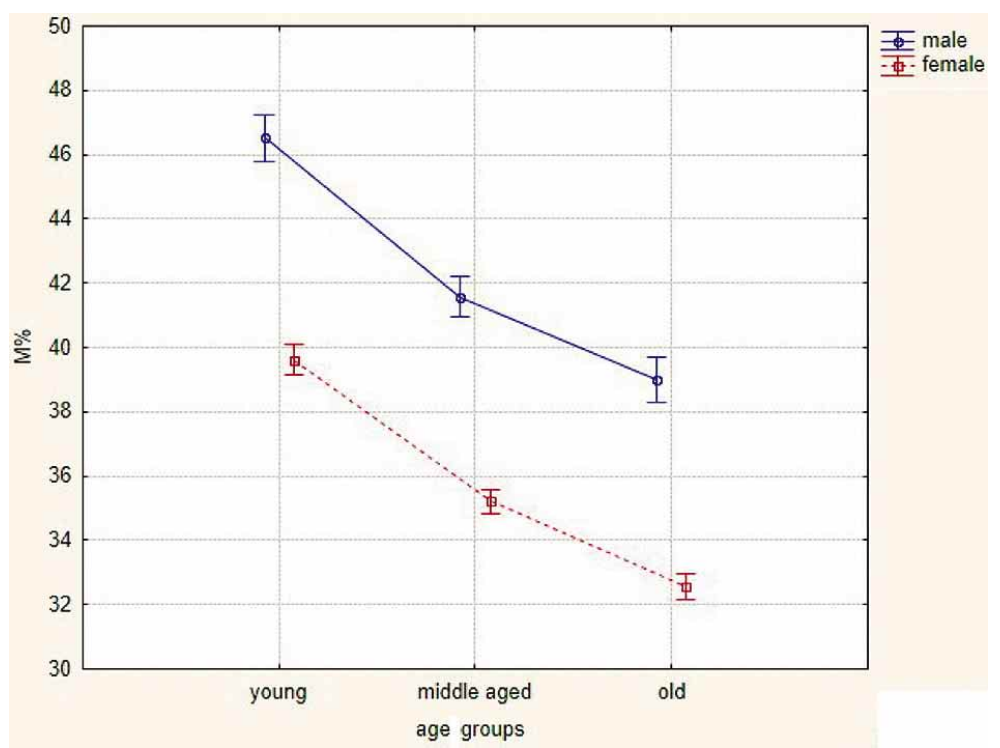

Fig. 3. Mean Percent Muscularity (M\%) for males and females by age group.

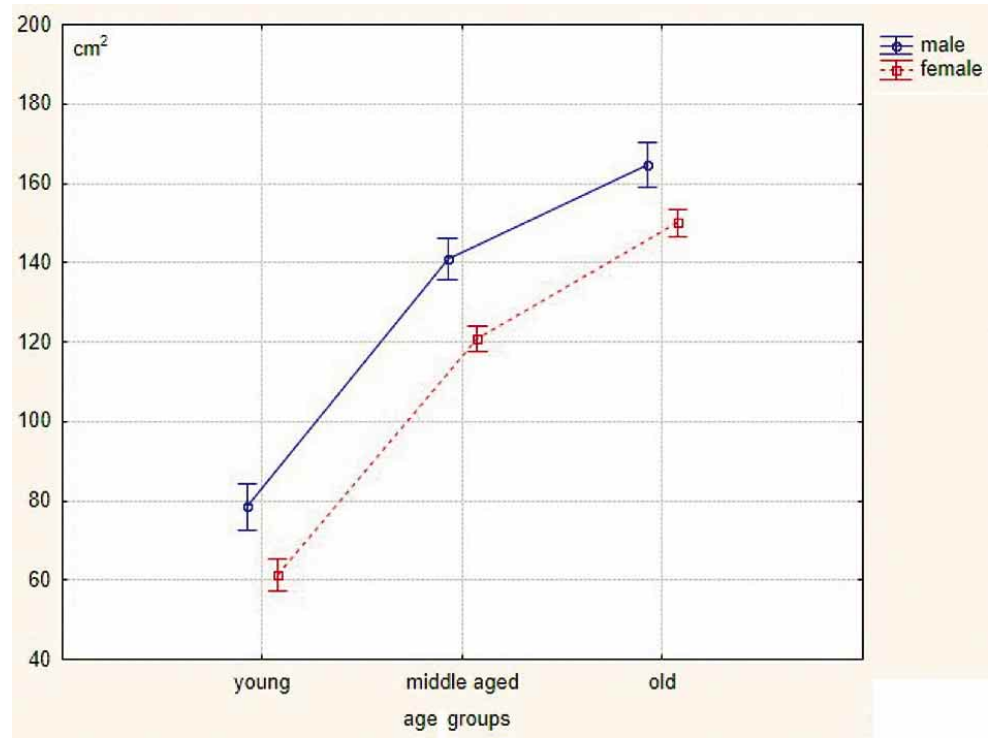

Fig. 4. Mean Visceral fat area $\left(\mathrm{cm}^{2}\right)$ for males and females by age group.

\section{DISCUSSION}

This descriptive study illustrates the changes in BMI and body composition across three age groups. Given that BMI did significantly change for this study population, it could be assumed that alterations in body composition are occurring. These changes were evident when reflecting on the changes in PBF and $\mathrm{M} \%$ across the age groups young to middle-aged, however not for older males. In comparing the percentages of fat to muscularity in this sample, these two components of body composition crossed in the middle years for females (adiposity higher than muscularity); whereas males approach equality (muscularity was always higher than adiposity).
The sharp increase in BMI from young to middle-aged adults was not expected considering the differences in body composition (reduction in muscularity and increase in fat). A sedentary and institutionalized lifestyle with little variety in daily activity and programing has a negative effect on physical fitness status, body composition, and quality of life. Self-motivation, active lifestyle, and regular and varied programs seem to have leading roles in the quality of life in elder population (Barthalos et al., 2012). The WHO body fat percentage recommendations (Gallagher et al., 2000b) show a 2-3\% increase in comparing the age categories. The actual mean increases from 4-8\% between these age categories for PBF was much higher and therefore might be unique to this study population.

The decline in percentage muscularity is not expected in transition from young adult to middle-aged adults. The 4-5\% decline on average observed from in both sexes for this study population might be based upon changes in lifestyle. That said, the continued decline in muscularity could be associated with lose of independent and possible cause of death in older adults. When there is an increase in fat mass, there is a reduction in muscle strength, physical capacity, and quality of life, along with a loss of fat-free mass (Katula et al.). The lean mass index, rather than the body mass index has been suggested as the stronger indicator of mortality in an older Asian population (Han et al., 2010). Low mortality values and less muscle fat have even been linked to an increase in aerobic exercise through walking speed (Woo et al., 2013). Combined program of aerobic and pilates, carried out under the supervision of an instructor, at least twice a week, produces health benefits in functionally independent women over the age of 60 (Ruiz-Montero et al., 2014).

In conclusion, this study justifies widespread assessment of body composition as well as measures of body size (stature and body mass). While the standard anthropometric methods incorporated in medical practice are beneficial, the need to identify whole body alterations persists as people age. As we move to better understand the impact of obesity prevention and treatment strategies, identifying the changes in body composition are necessary. 
IHÁSZ, F.; FINN, K. J.; LEPES, J.; HALASI, S. \& SZABÓ, P. Comparaciones de composición corporal en grupos etarios de adultos húngaros. Int. J. Morphol., 33(3):850-854, 2015.

RESUMEN: La evaluación de la composición corporal proporciona una base para evaluar cambios en adultos a medida que envejecen. Al determinar que el contenido de grasa es demasiado alto, se justifica la intervención para reducir esta grasa de almacenamiento. El propósito de este trabajo fue reportar las diferencias en la composición corporal en hombres y mujeres de tres grupos etarios (jóvenes, de mediana edad y adultos mayores) para describir los cambios potenciales en grasa y musculatura. Además, el almacenamiento de grasa que se encuentra en la zona visceral (alrededor de los órganos internos) constituye un riesgo importante para la salud. Un total de 1564 adultos húngaros fueron incluidos en el estudio para definir el índice de masa corporal (IMC) y la composición corporal utilizando un dispositivo de impedancia eléctrica de múltiples frecuencias para determinar el porcentaje de grasa corporal $(\mathrm{PBF})$, porcentaje de la musculatura $(\mathrm{M} \%)$ y el área de grasa visceral. Fue realizadoun análisis descriptivo y de varianza para comparar los valores medios de cada uno de los tres grupos. Comparaciones post hoc se realizaron en los hallazgos significativos. Los resultados indicaron un aumento en el IMC, PBF y área de grasa visceral, y una disminución de M\%. Estas diferencias fueron evidentes en los jóvenes, a diferencia de los adultos de mediana edad y de edad avanzada, como también entre los adultos de mediana edad y adultos mayores. Los niveles de musculatura fueron significativamente menores a medida que la edad avanzaba. Esto dio lugar a diferencias significativas en el IMC entre los adultos de mediana edad y adultos mayores. Esta reducción de la musculatura es alarmante debido a que antes de la edad prevista para la sarcopenia, los adultos de mediana edad muestran disminución en el tejido que beneficiaría la calidad de vida. Se requieren estudios longitudinales para confirmar estos hallazgos.

PALABRAS CLAVE: Composición corporal; Grupos etarios; Hombres; Mujeres.

\section{REFERENCES}

American College of Sports Medicine; Chodzko-Zajko, W. J.; Proctor, D. N.; Fiatarone Singh, M. A.; Minson, C. T.; Nigg, C. R.; Salem, G. J. \& Skinner, J. S. American College of Sports Medicine position stand. Exercise and physical activity for older adults. Med. Sci. Sports Exerc., 41(7):1510-30, 2009.

Bae, C. Y.; Kang, Y. G.; Suh, Y. S.; Han, J. H.; Kim, S. S. \& Shim, K. W. A model for estimating body shape biological age based on clinical parameters associated with body composition. Clin. Interv. Aging, 8:11-8, 2013.

Barthalos, I.; Bognár, J.; Fügedi, B.; Plachy, J. \& Ihász, F. Physical performance, body composition, and quality of life in elderly women from clubs for the retired and living in twilight homes. Biomed. Hum. Kinet., $4(1): 45-8,2012$.

Bedogni, G.; Malavolti, M.; Severi, S.; Poli, M.; Mussi, C.; Fantuzzi, A. L. $\&$ Battistini, N. Accuracy of an eight-point tactile-electrode impedance method in the assessment of total body water. Eur. J. Clin. Nutr., 56(11):1143-8, 2002.

Gallagher, D.; Ruts, E.; Visser, M.; Heshka, S.; Baumgartner, R. N.; Wang, J.; Pierson, R. N.; Pi-Sunyer, T. X. \& Heymsfield, S. B. Weight stability masks sarcopenia in elderly men and women. Am. J. Physiol. Endocrinol. Metab., 279(2):E366-75, 2000a.

Gallagher, D.; Heymsfield, S. B.; Heo, M.; Jebb, S. A.; Murgatroyd, P. R. \& Sakamoto, Y. Healthy percentage body fat ranges: an approach for developing guidelines based on body mass index. Am. J. Clin. Nut., 72(3):694-701, 2000b.

Gibson, A. L.; Holmes, J. C.; Desautels, R. L.; Edmonds, L. B. \& Nuudi, L. Ability of new octapolar bioimpedance spectroscopy analyzers to predict 4-component-model percentage body fat in Hispanic, black, and white adults. Am. J. Clin. Nutr., 87(2):332-8, 2008.

Han, S. S.; Kim, K. W.; Kim, K. I., Na, K. Y.; Chae, D. W.; Kim, S. \& Chin, H. J. Lean mass index: a better predictor of mortality than body mass index in elderly Asians. J. Am. Geriatr. Soc., 58(2):312-7, 2010.

Katula, J. A.; Sipe, M.; Rejeski, W. J. \& Focht, B. C. Strength training in older adults: an empowering intervention. Med. Sci. Sports Exerc., 38(1):106-11, 2006.
Romero-Corral, A.; Somers, V. K.; Sierra-Johnson, J.; Thomas, R. J.; Bailey, K. R.; Collazo-Clavell, M. L.; Allison, T. G.; Korinek, J.; Batsis, J. A. \& Lopez-Jimenez, F. Accuracy of body mass index to diagnose obesity in the US adult population. Int. J. Obes. (Lond.), 32(6):959-66, 2008.

Rosenberg, I. H. \& Roubenoff, R. Stalking sarcopenia. Ann. Intern. Med., 123(9):727-8, 1995.

Ruiz-Montero, P. J.; Castillo-Rodrigez, A.; Mikalac `ki, M.; Nebojsa, C. \& Korovljev, D. 24-weeks Pilates-aerobic and educative training to improve body fat mass in elderly Serbian women. Clin. Interv. Aging, 9:243-8, 2014.

Shafer, K. J.; Siders, W. A.; Johnson, L. K. \& Lukaski, H. C. Validity of segmental multiple-frequency bioelectrical impedance analysis to estimate body composition of adults across a range of body mass indexes. Nutrition, 25(1):25-32, 2009.

Sun, G.; French, C. R.; Martin, G. R.; Younghusband, B.; Green, R. C.; Xie, Y. G.; Mathews, M.; Barron, J. R.; Fitzpatrick, D. G.; Gulliver, W. \& Zhang, H. Comparison of multifrequency bioelectrical impedance analysis with dual-energy X-ray absorptiometry for assessment of percentage body fat in a large, healthy population. Am. J. Clin. Nutr., 81(1):74-8, 2005.

Woo, J.; Yu, R. \& Yau, F. Fitness, fatness and survival in elderly populations. Age (Dordr.), 35(3):973-84, 2013.

World Health Organization. Obesity: preventing and managing the global epidemic. Report of a WHO consultation. World Health Organ. Tech. Rep. Ser. 894:1-253, 2000.

\section{Correspondence to: \\ Dr. Josip Lepes \\ University of Novi Sad \\ Teachers' Training Faculty in Hungarian \\ Strossmayer str. 11, 24000 \\ Subotica \\ SERBIA}

Email: lepes@tippnet.rs

Received: 28-01-2015

Accepted: 01-06-2015 